\title{
ARE CHILDHOOD CRUELTY TO ANIMALS INDICATES AS MENTAL DISORDER?
}

\author{
Risa Juliadilla* \\ Program Studi Psikologi, Fakultas Ilmu Sosial dan Budaya, Universitas Gajayana Malang \\ risajuliadilla@unigamalang.ac.id
}

Nia Anggri Noveni

Fakultas Psikologi, Universitas Muhammadiyah Purwokerto

\begin{abstract}
Animal Cruelty regularly happened during childhood that indicates beyond cruelty to humans. Cruelty to animals distinguishes some steps: curiosity, exploration, imitates or even the aggressive act refers to animal cruelty. The ignorance toward these aggressive acts led to Conduct Disorder or even Antisocial Personality Disorder. Animal Cruelty reached an agreement as to the unethical act with intentional tortures, unintentionally suffering causes death. Cruelty is done on purpose and with intentional time. This research aims as a reference for animal cruelty in childhood by proposing some research summary in (1) Animal Cruelty framework, (2) Animal Cruelty relation among child abuse and domestic violence; (3) Developmental Psychology reference: Children aggressive acts toward animal; (4) animal cruelty and psychology disorder and (5) clinical pathway childhood cruelty to animals. The research conducts a literature review by describing a theory, discussion, and results from textbooks, articles, and journals. This article had synthesized 16 research articles that have been identifying through an online database and manual search for selected research. The researcher analyzed, compared the results taken from some literature, identifies the pros and cons, and proposing findings and discussions. In conclusion, animal cruelty defines as a crucial marker for mental health that relates to Conduct Disorder to Antisocial Personality Disorder. The role of adults is vital in minimizing children's acts for committing animal cruelty by nurturing empathy. Humane education program is one of efforts to teach empathy since early childhood.
\end{abstract}

Keywords: Animal Cruelty, Childhood, Conduct Disorder, Antisocial Personality Disorder

\begin{abstract}
Abstrak: Kekejaman pada hewan sering muncul di masa kanak-kanak yang dapat mendahului kekerasan pada manusia di kemudian hari. Perilaku kekejaman pada hewan terjadi bertahap mulai dari rasa ingin tahu, eksplorasi, meniru perilaku, hingga perilaku agresif yang bertujuan menyakiti hewan. Perilaku agresif pada hewan yang dibiarkan dapat membentuk anak mengalami Conduct Disorder (CD) hingga Antisocial Personality Disorder (APD). Tujuan dari penelitian ini memberi tinjauan tentang perilaku kekejaman pada hewan pada saat masa kanak dengan menawarkan ringkasan studi tentang (1) konsep kekejaman pada hewan; (2) hubungan kekerasan hewan, kekerasan pada anak dan kekerasan rumah tangga; (3) tinjauan developmental psychopathology : tindakan kekejaman anak pada hewan; (4) kekejaman pada hewan dan gangguan psikologi; (5) jalur klinis tindak kekerasan anakanak pada hewan. Artikel ini disusun menggunakan kajian literatur yaitu uraian tentang suatu teori, temuan dan bahan penelitian lain yang diperoleh melalui buku, artikel-artikel jurnal penelitian. Ulasan ini mensintesis 16 artikel yang diidentifikasi melalui database online dan pencarian manual pada studi yang ditentukan. Peneliti kemudian menganalisis, membandingkan hasil penelitian satu dan lainnya, mencari kesamaan dan perbedaan serta meringkas dan membuat kesimpulan.
\end{abstract}

* Author Correspondence 
Kesimpulan dari penelitian ini adalah tindakan kekejaman pada hewan merupakan suatu catatan yang serius untuk kesehatan mental yaitu Conduct Disorder (CD) hingga Antisocial Personality Disorder $(A P D)$. Pentingnya peran orang dewasa untuk menimalisir tindakan anak dalam melakukan kekejaman terhadap hewan dengan mengembangkan sikap empati. Humane education merupakan salah satu upaya untuk mengajarkan empati sejak dini.

Kata kunci: Kekerasan pada hewan, Masa Kanak, Gangguan Tingkah laku, Gangguan Kepribadian antisosial 


\section{INTRODUCTION}

The following acts that occurred at childhood times define as the trigger of future aggression to humans including animal cruelty, enuresis, and firesetting. When children does these acts at the same time or combined acts led to future aggressiveness. The predicted things in adults are the emergence of cruel sexual behavior, firesetting, committing crime, or murder (Chan \& Wong, 2019). According to MacDonald Triad components, enuresis displayed as the weak connection of the aggressive and crime at present. Besides, firesetting and cruelty to animals prove correlation to cruelty and crime (Walters, 2016). As well as cruelty to animals has comprehensive theoretical study compared to enuresis, and firesetting (Chan \& Wong, 2019). The research conducted by Walters (2016) to 496 male with sex offenders shows the results that cruelty to animals is classified as a sign of callous and uncompassionate. Cruelty to animals performs as an alert of psychological risk factors for developmental problems of children. These actions indicate that the child needs to get clinical treatment in purpose to avoid the nurture of personality with violence. Children who engage in animal cruelty 3 times or more are likely to commit more serious crimes including murder, rape, robbery, assault, harassment, threats, and abuse of drugs or substances (Johnson, 2018).

Here are two stories for clear relationship:

"From the initial investigation conducted by the police, NF (15 years old), adolescents killer 5-year-old boy got some facts, one of them is the perpetrator are often abuse animals. She can torture a frog or lizard with a fork. Then when she was upset, her cat thrown from the second floor "(Wijana \& Anggreini, 2020) "DCL (6 years old) was found sobbing in the hospital when he rushed to bring a dead chick that struck as he was playing a bicycle. He took the dying chick to nearby hospitals and gave all the money to ask help from a nurse (Camelia, 2019)

The news above distinguishes two different situations, the first is emphasizes that animal cruelty prone as the practice before committing a crime to human, and the second one shows the empathy and responsibility of children. Cultivating empath for early childhood is a fundamental basis of prosocial acts. One idea to acknowledge children about the lesson of an empath can determine by human-animal interaction. Childhood world associate with animals through fable, animal doll, imitating the animal sound and science. So that, learning empathy helps by animals object is the right decision.

Teaching for animal welfare to children is an effort that can foster empathy. The aim is to improve the awareness to treat the animal with respect and minimize the acts of animal cruelty. A survey report was taken from students in Greece, Italy, and Spain and came with the fact that they had an understanding but lack of knowledge on animal welfare. Knowledge of animal welfare depicts the way how we treat the animal. This issue becomes the point of discussion specifically in the Europe Union, and as a result, they introduce the program regarding animal welfare. Austria is an example for those that apply for animal 
welfare programs for their middle school (Protopapadaki, 2016).

Children commit acts of violence and cruelty as they as victims of what they learn around them (Hensley, Tallichet, \& Dutkiewicz, 2012). Animal cruelty from moderate to severe is widespread in our society, but some people are still not fully aware. In the beginning, children make fun by pulling animal tails, chasing them to make them afraid, neglecting them by not providing sufficient food, or imprisoning them in a narrow cage. Animal cruelty defines as when children are committing violence by hitting or dismembering the animal. Adults are unintentionally committing cruelty to animals regularly at a light level that children can imitate.

Cases of animal cruelty are frequently committed by adults and children. Garda Satwa Indonesia found 103 animal cruelty cases in 2015 that raise per year. The phenomenon has been spotted in the massive news of animal cruelty cases. Garda Satwa Indonesia found 103 cases of animal cruelty in 2015 and increase per year (Wellson \& Gandha, 2015). The phenomenon has been spotted in the massive news of animal cruelty cases. Later, the perpetrator did not hesitate to post on social media. Thus, legal sanctions for perpetrators of animal abuse cases remain weak and lack action.

At this point, the cycle of animal violence remains to exist and unfortunately children are indeed commit cruelty to animals. In 1964, Margaret Mead, a social scientist, said that perpetrators of animal cruelty in childhood potentially commit violence and murder repeatedly if not got treated up (Jegatheesan, Enders-Slegers, Ormerod, \& Boyden, 2020).

The role of parents and adults is vital to respond to the animal cruelty phenomenon. So that, the animal cruelty concepts comprehend to get in-deep result overview. The research aims to sketch up summarize of animal cruelty in childhood by preserving reviews relate to (1) The concept of animal cruelty, (2) The relation on animal cruelty, child abuse, and domestic violence, (3) Developmental Psychopathology overview, (4) Animal Cruelty and Clinical Disorders, (5) clinical pathway childhood cruelty to animals.

\section{Methodology}

The article uses the literature review as a research methodology with review literature, findings, and other sources are taken from books, articles, and journals. This article had synthesized 16 research articles that have been identifying through an online database and manual search for selected research. In the beginning, the researcher collected the literature by collecting data from journals with a particular focus: cruelty animals, Conduct Disorder (CD), antisocial personality disorder (APD), and Psychopath. The next step is the researcher collecting, analyzing, processing the data, and comparing the results one to another, sythesizing, and draw the conclusion.

\section{Result and Discussion \\ Concepts of Animal Cruelty}

In the beginning, describing the concepts of animal cruelty requires enormous effort since the dichotomy of animals' existence is considered for daily 
consumption, as the opposite, humans urge to think about the animals' welfare. The definition of cruelty to animals has been established as unethical behavior with intentional tortures, and unintentionally suffering causes a death. The behavior pattern is intentionally and repeatedly (Gullone, 2012). Animals cruelty, in the literature on human aggression is horrendous than the dimensions of hostility, for example, burned alive and extreme torture. The perpetrators' sight thinks animals as livestock that bred, insult, and pests (Gullone, 2012). On the other hand, some people upgrade the status as companion animals or pets where the owners will regard them as family members and provide care (Gullone, 2012).

Animal Cruelty to the high values animal (i.e, a pet: dog) tends to connect with cruelty to humans rather than cruelty to low-value animals (i.e, cockroaches, mouses, etc.). However, the perpetrators that do the cruelty with purposes are considered deviant behavior. Cruelty to animals that are done purposely and torturing to death is abnormal and criminal that is socially and legally unacceptable (Gullone, 2011). Animal cruelty means omitting particulars activities such as hunting, farming, veterinary practice, animal farming, animal testing, and animal worship. Those activities are accepting by society and no direction to pathology (Gullone, 2012). Cruelty animal is not restricted only to active acts: hitting, kicking, torturing but also to passive ones: neglecting, by not preserving sufficient food and drinks (Levitt, Hoffer, \& Loper, 2016). In short, animal cruelty is culturally opposed and deviance when it does in purposes, painful and frequently.

Some researchers created an inventory to precisely measures the definition of animal cruelty, as one of them is The Cruelty to Animals Inventory (CAI) that developed by Dadds et al., (2004) . CAI adequate to concede of nine aspects of the cruelty of children as follows: severity (based on degree of intentional pain and injury caused to an animal), frequency (the number of separate acts of cruelty), duration (period of time over which the cruel acts occurred), recency (the most recent acts), diversity across and within categories (number of animals abused from different categories and the number of animals harmed from any one category), sentience (level of concern for the abused animal), covertness (child's attempts to conceal the behavior), isolation (whether the cruelty occurred alone or with other children/adults), and empathy (the degree of the child's remorse for the cruel acts).

The animal cruelty motive of childhood have various and complicated reasons, and it is necessary to understand the characteristics and situational circumstances of the perpetrator. This way is helpful to predict future violence that might divert into violence to humans. According to Ascione, there are three types of the background of children and adolescents to engage in the acts underlying cruelty to animals (Hawkins, Hawkins, \& Williams, 2017):

1. Exploratory animal abuse. In general, accidentally perform by children with curiosity and lack of knowledge, direction, and 
supervision from adults and environment.

2. In pathology, torturing animals means a sign of the clinical treatment needs causing by psychological distress symptoms, i.e. personality and behavior, or other mental disorders. This category is also done by children or older.

3. Delinquent animal abuse is cruelty to animals that reflect the pattern of delinquent behavior and various antisocial acts. Mostly found in adolescents, that desired by childhood experiences, peer effects, imitating behavior, animal abuse related to sexual satisfaction, particular animal phobias, and traumatic experiences.

One of the points to concern is the existence of remorse. In short, when children have not shown any remorse after committing cruelty to an animal, that is an indication that leads to psychopathology.

\section{The Connections of Animal Cruelty,} Child Abuse and Domestic Violence

Animal cruelty and cruelty to humans had a strong bond, which that phenomenon knew as linked. The perpetrators found that also committed cruelty to humans. (Jegatheesan et al., 2020) describes behavior patterns when adults commit violence linked to childhood experiences, especially for children who have a background of cruelty to animals in childhood. Unpleasant experiences in childhood or the family role malfunctions are risk factors of children to get behavioral disorders. The emergence of cruelty to animals might start when children were imitating their parent's violent behavior, by then unable to develop an attitude of empathy, and that behavior was absorbing from the surroundings. The role of parents toward cruelty to animals was dominant when parents show aggressive behavior to a non-human, it is likely the child imitates their parents act, including cruelty to animals.

Animal cruelty is the result of children learning experience by watching the cruelty acts or experiences as the victim of domestic violence (McEwen, Moffitt, \& Arseneault, 2014). The patriarchal system dominated nurturing violence in the community that commonly happened to women also the pet who is considered a family member. Patriarchy was prone to displaying domination and control to all family members. Domestic violence is the most powerful is equal to violence that contributes by the father in the form of violence to wife and physical punishment to family members (Gullone, 2011). The perpetrators are creating terror for the partner and children. This makes a related system regarding animal cruelty, child abuse, and domestic violence (Jegatheesan et al., 2020).

This violence comes as a chain of violence when children were victims of violence in the family or experiencing to see violence against animals. Children who had nurtured beyond this situation are more likely to commit cruelty to animals than children who do not experience violence at all. Animal abuse can perform as a transfer of aggression to weaker objects. The transfer of aggressiveness to animals can turn defenseless to control and empowerment. Someone can have a sense of control 
through persecution and desired to repay for feelings of weakness (Gullone, 2011). This behavior is done to derive pleasure from the disorder. Although few children were experiencing violence in the family face the same problems, some are successful, able to adapt, and increase resilience. Family is the first microsystem for children. Family for children functions as the initial foundation to shape personality and character. When children had nurtured by inappropriate it will cause emotional and developmental disorders. Inharmonious relations within family members is one of the causes of behavioral disorders in children.

\section{Developmental Psychopathology: Acts of child cruelty to animals}

The act of animal cruelty in childhood had assessed using psychological theories of human development. Hawkins \& Williams, (2017) explain that animal cruelty has an impact on psychological development. The acts of animal cruelty by children occurs gradually. If not treated immediately, animal cruelty can predict children's behavior from adolescence to adulthood, such as identifying antisocial personalities or psychopaths. Factors that affect animal cruelty include peer influence, imitation behavior, mood, sexual satisfaction, animal abuse, attachment to animals, animal phobias, and experiencing abuses. Hawkins et al., (2017) add the trigger for children to do cruelty to animals during childhood are violence during childhood time, neglected children, bullying, behavioral, personality, mental \& health, family dysfunction, sexual violence, lack of empathy, weak coping strategies, and problems with peers. When parents scolding vigorously, it can lead to aggressive behavior that motivates the cruelty of animals. The children's acts to demonstrate aggressive behavior with cruelty to animals can develop further imagination to its aggression and this condition are even getting worse when the ignoring environment, neglecting children behavior or even becomes the victim of bullying. Children's aggressive behavior in the form of animal cruelty may distract the growth of empathy that resulted in an empathy deficit disorder. Normative levels of empathy in childhood can serve as a protective barrier against aggressive behavior. Particularly, when children feel from the perspective of animals. When children can feel from an animal perspective, it can affect the actions when children treat animals.

McDonald et al., (2018) stated that animal cruelty has been reproducing by aggressive behavior when commiting cruelty to animal. According to Hawkins \& Williams, (2017) it has explained that childhood experiences related to parenting patterns with neglecting their children may trigger the children to commit cruelty to animals that have occurred by low-supervision, lack of knowledge to treat animals properly. Further observation is needed for adolescence whether the experience of committing cruelty to animals in childhood can be a potential pattern for juvenile delinquency to antisocial behavior. In adolescents, acts of cruelty to animals in most cases arise because of peer-pressure as reinforcing the behavior of adolescents, including being cruel to animals. Besides, the problem of animal 
cruelty by adolescence is related to unpleasant childhood experiences.

Kellert and Felthous also suggest the main backgrounds why humans, especially children, engage in cruel behavior to animals as follows (i) attempts to control the animal (e.g., hitting a dog to stop the barking), (ii) retaliation (i.e., cutting a cat's leg for having stolen food, (iii) acted out of prejudice against a particular species or race, (i.e., despising dogs for being unclean), (iv) expressions of aggression through animals (e.g., organizing dog fights) or, (v) acting on motivation to increase one's aggressiveness (i.e., animals are purposes to attract attention), (vi) to surprise people for entertainment (observable harassment of others), (vii) to retaliate against others or as revenge (e.g., killing or injuring unwanted neighbors), (viii) transfer of aggression to animals, and (xi) nonspecific sadism a desire to cause suffering, injury, or death but the absence of certain feelings or hostility towards animals (Chan \& Wong, 2019).

\section{Learning of Aggression to Cruelty of Animals}

Social learning theory by Bandura explains when people learn about the how and why they engage in any behavior, including criminal and deviant behavior. The process is similar when children see adults in their inner circle (Hensley et al., 2012). This theory can explain the etymology of the environmental factors that cause antisocial behavior and aggression. In particular, the environmental factors such as violence at home, observing violence against animals like how adults treat animals since our acts connected to the learning process both in the family and environment. Learning for individuals occurs through a process of observation and imitation. Learning has defined as the ability to learn from the social environment, especially when children observing adults.

Bandura's research on adults who treats bobo doll brutally then let the children observing the behavior, the effect is the children become more aggressive in treating dolls. Bandura in Santrock, (2011) explained that particular situation as the aggression transference by imitating the aggressive behavior. Bandura's work on Bobo Doll describes the work of phenomenon when children imitate the adults by observing their behavior. Bandura shows that the social learning process begins with someone observing, modeling, then imitating that taken from the recent experiences of others, before the child is confident and independent in performing their behavior.

The human imitating behavior was driving by imitating behavior from surroundings like family, community, and broader surroundings. The process of imitating behavior began at 0-1 year. Children at an early age (0-1 year) imitate the adults' facial expressions and gestures. Besides that two fundamental behavior, children replicate simple behavior such as kicking or hit with hands. Children can observe and imitate the simple behavior from their surroundings, such as family. In particular, children imitated the adults' behavior in kicking (hurt) animals.

The process of imitating behavior at three years old children becomes intricate. For three years old the process is more detailed and not only observing the behavior but also involving the cognition steps. At this stage, children emerge from 
their high sense of curiosity about the things around them. Children with intense curiosity encourage a sense of exploration when getting positive feedback from the inner circle like family. The positive feedback that is given in responding to children's curiosity stimulates the children to get intimate learning.

Children's cognitive development emerges by imitating the violent acts associated with a parenting style related to emotion management. McEwen et al., (2014) said that children who commit cruelty to animals indicate suffering abuse from their parents. Although when children mistreat the animals are not necessarily intended to hurt or molest. Lack of supervision and the neglecting parenting style turns to negative behavior by committing cruelty to animals. For seven years old children, their actions and emotions are affected by the response of adults, so that the parents' responses is crucial.

Maladaptive learning has been discovered in parents with an indifferent attitude towards children, parents being permissive over their child's aggressive behavior, the use of corporal punishment, and authoritarian rule (Gullone, 2011). The child's behavior in the animal cruelty context generates a sense of interest and desire to explore and no desire to hurt. At this point, the children were learning to see animal expressions and gestures associated with children's behavior in the following times. The way of treating animals can be more aggressive as the process of imitating adults. Adults validation to the violence committed to the animal is required, like when children imitate behavior around them, such as kicking an animal and their parents do not provide any guidance to their acts, so children might think that their behavior is correct.

\section{The Violence Graduation Hypothesis}

The approach aims to predict that individuals who commit cruelty to animals in childhood expect to have more severe cruelty acts to humans. Animal cruelty means a cycle begins with a fight, persecute, so animal cruelty is the most brutal (Johnson, 2018). If the situation is left untreated, it is likely to develop into an uncompassionate and unemotional trait setting up a dangerous generation. Through cruelty to animals, children may learn to enjoy feeling to suffer the objects to do the same to a human. The phenomenon involved several cases in Indonesia, a teenager (NF) who murder a toddler, when in her daily frequently tortures and kills animals, such as frogs and lizards that stabbed with a fork and once she had thrown her cat when she was upset.

Hensley, Tallichet, \& Dutkiewicz, (2012) carried out a study on 180 male prisoners, found that 108 of 180 said they had involved cruelty to animals in childhood. The torture categories as follow: bumping $(\mathrm{n}=85,82.5 \%)$, kicking ( $\mathrm{n}$ $=37,35.9 \%)$, shooting $(\mathrm{n}=34,33 \%)$, committing sexual harassment $(n=23,22.3$ $\%)$, drowned $(\mathrm{n}=18,17.5 \%)$ choked $(\mathrm{n}=$ $18,17.5 \%)$ and burned ( $\mathrm{n}=16,15.5 \%)$. When they commit cruelty to animals without any emotional feelings. When some respondents did sexual abuse animals, thus they tended not to jump out of the closet. In contrast to previous 
research by Hensley \& Tallichet, (2005) surveyed 261 prisoners found that onethird of the sample committed cruelty to animals for fun apart from that due to the angry response that was vented on animals. Prisoners who indulge in cruel behavior on animals tend to do so when alone, in contrast to inmates who act in front of others to impress people and imitate others.

\section{The Deviance Generalization Hypothesis}

Animal cruelty as a part of various antisocial behavior can precede or track to other types of behavior such as misleading, stealing, property destruction, robbery, sexual assault, and other violence. This theory substance states that if an individual performs deviant behavior, it tends to commit other deviations. Perpetrators of animal cruelty usually have a record of drug and alcohol abuse or have history of a family with antisocial behavior (Chan \& Wong, 2019).

\section{Animal Cruelty and Psychological Disorders \\ Conduct Disorder (CD)}

The animal cruelty issue is yet on the list of antisocial behavior symptoms in childhood and adolescence released by DSM in 1980. DSM-III-R first editions launched in 1987 attach animal cruelty issues as the symptoms of Conduct Disorder (CD) and kept up to DSM-V. The firsts pioneer was Tapia in 1971. His research assessed the connection between animal cruelty to mental illness and, some researchers do similar research. Recently, animal cruelty became the current topic in DSM next edition, IV, IV-TR dan V, APA 1994, 2000, and 2013 (Ascione, McDonald, Tedeschi, \& Williams, 2018).
Animal abuse proves as clinical diagnostics that the acts are a severe case and requires assistance to defend the children not to become a killer (Jegatheesan et al., 2020). Cruelty to animals is one of the criteria of Conduct Disorder in DSM-V. Conduct Disorder characterized by repeated and persistent aggression and violations to other people and animals. According to DSM-V (American Psychiatric Association., 2013), some other criteria are the destruction of property, robbery, and theft, and severe breaches of rules. The behavioral disorders cause by not a single factor but bio psychosocial. Some of the causes by adverse parenting styles and intense family conflict. Children who had exposed to a chaotic family situation show unstable emotions. And it might cause the children to lack self-regulation so that they are less experienced in coping with stress, moral development, and empathy (Pradnyawati \& Ardjana, 2015).

Conduct Disorder diagnosis attached with a clinical determinant, Limited Prosocial Emotion (LPE) with an improved dimension. The clinical determinants used to identify Conduct Disorder with callous or unemotional characteristics. Children who are diagnosed with both Conduct Disorder and $\mathrm{CU}$ defines as the more aggressive group. Conduct Disorder may occur at 5 to 6 years old but is more common in late childhood or early adolescence. Conduct Disorder in childhood can perform as a psychological prediction for other disorders such as delinquency, drug abuse, dropping out of school, suicide, and teenage crime. The frequency of animal abuse mostly found at mean age of 6.5 y.o included fighting (6 y.o), 
bullying (7 y.o), and assault (7.5 y.o). As many as $25 \%$ of children with a diagnosis of CD performed cruelty to animals. Animal cruelty had grouped as a destructive group (Gullone, 2011). Thus, the statement supports the continuity claim that $\mathrm{CD}$ can develop into Antisocial Personality Disorder (APD) as adults.

\section{Antisocial Personality Disorder (APD)}

Antisocial Personal Disorder correlates with CD since animal cruelty simultaneously occurs with the suppression behavior. Gleyzer et al., (2002) emphasized the antisocial personality disorder diagnosis have a considerable correlation with childhood cruelty. Individuals with APD are likely to have a record of animal cruelty behavior. Animal Cruelty is part of the antisocial behaviors associate with childhood CD, becomes a diagnosis of APD. Disrespecting and violating others are part of APD patterns arise to adolescent which fails to follow social norms, i.e: performs fraud, aggressiveness, irritability, irresponsibility, and no remorse for unfavorable treatment. APD is also deceitful, irresponsible, and manipulative.

The similarity of pathological personality traits Conduct Disorder with Antisocial Personal Disorder based on DSM-V (American Psychiatric Association., 2013) is an empathy deficit showing lack of sensitivity, lack of feelings, understanding of the needs, and understanding the suffering of others. Furthermore, there are no regrets to others after doing acts of aggression. Another similarity is deceitfulness, for example, deception or story fabrication. In general, individuals with APD look usual or even charming and pleasant. The individual with APD can track his / her daily life into calm and trustworthy to cover up his falsehood (Hervey Cleckley, the mask of sanity). This pattern is also known as psychopathy, sociopathy, and social personality disorder (American Psychiatric Association., 2013). Nowadays, society recognized APD with the terms psychopath and sociopath.

Several cases of persecution and murder are frequently associated with psychopaths and sociopaths, but they need to generate explores. Psychopaths and sociopaths are closely related to the diagnosis of APD (Johnson, 2019). Psychopathy was conceptualized by Cleckley and clarified by Hare. He describes different perspectives regarding psychopaths concepts when he thought that both psychopaths and antisocial personalities were distorted. Most people with antisocial personality are not psychopaths, whereas most psychopaths meet the diagnostic criteria for antisocial personality disorder (Hare \& Neumann, 2009).

\section{Clinical Pathway Childhood Cruelty to Animals}

Animal cruelty in childhood originated from the curiosity to know and appreciate animals. When adults do not supervise and neglect their children, then they might think that the acts are correct. Animal cruelty discharge from trivial things, such as abandoning pets, hitting, and torturing that cause death.

Children that commit animal cruelty implies to what they have seen around like family or friends. Family is the 
first child's eco-system. When a child becomes a victim or sees violence at home, within all the pressure and harsh physical treatment, the child will also imitate the aggressive behavior that has been seen or felt. Children can perform displacement on weaker objects such as pets and animals around. The existence of animal abuse turns somebody to feel powerful and empowered. Animal cruelty is a delicate subject and is a symptom of CD.

$\mathrm{CD}$ can precede or coincide with other mental disorders, which is the focus of developmental psychopathology. There are two characteristics of behavior disorders: internalizing behavior in the form of social rejection, anxiety, and depression while externalizing behavior is aggressive (including in animals and humans), violates hyperactivity rules (Nunes, Faraco, Vieira, \& Rubin ,2012). DSM-V (American Psychiatric Association., 2013) added identification of CDs, called Limited Prosocial Emotions (LPE) with a lack of remorse or guilt and Callous-Unemotional (CU) traits because LPE is a determinant for assessing the behavior function of today's adolescents and in the future. Longman, Hawes, \& Kohlhoff, (2015) emphasized through meta-analysis research that $\mathrm{CU}$ is representing behavioral problems.

Some CD causal factors had developed during the prenatal period (i.e., abnormal fetal development and learning outcomes from the environment. Likewise, CU can be due to amygdala dysfunction. CD individuals who have CU have low neuropsychological performance. They have difficulty recognizing facial expressions of fear, sadness, and pain that consider something fun (Acquaviva, Ellul, \& Benarous, 2018).
CU can be associated with a temperament that can bring courage and beneath the concept of psychopathy. However, this study focuses more on $\mathrm{CU}$ as a result of socialization and the learning process. Children can absorb aggression from their surroundings, like family. In general, they are accustomed to seeing their father making a pet as a control. Animals can be used as a displacement to unleash anger and used as a means of control to compensate for weakness.

The presence of LPE predicts a stable or even more severe path of antisocial behavior that can continue into adulthood. If not managed quickly and appropriately, children with CD expand to antisocial personality disorder in adulthood (Pradnyawati \& Ardjana, 2015). CD with Antisocial Personality Disorder (APD) is often called Spectrum Externalization. This spectrum includes personality traits that are disinhibitors, such as impulsivity and aggression (Gullone, 2012). The callousness behavior integrated with externalizing behavior that turns to an antisocial personality.

One of the similar pathological personality traits that underlie $C D$ is Callousness and Deceitfulness. Lack of empathy accompanied by other pathological personality traits: manipulative, hostility, risk-taking, impulsivity, and irresponsibility is the focus. Aggression is more prepared and instrumental (to achieve particular goals) that in line with the violence graduation theory that proves animal cruelty may expand to aggressiveness to humans. Cruelty behavior to animals can perform as an experiment before committing to humans. Aggressive behavior also develops into antisocial behavior (The 
deviance generalization hypothesis): lying, stealing, robbery, sexual violence, and others (Gullone, 2014). Many researcher predict, antisocial and uncompassionate is an indication of psychopathic. However, further investigation show, there is a gap between sociopaths and psychopaths. That psychopath is a genetic or biological disorder, calmer, more preparation in performance, whereas sociopath is a result of environment or parenting that is more impulsive.

\section{Conclusion}

Animal cruelty committed in childhood is one of the characteristics of Conduct Disorder (CD). Regardless the child is diagnosed with CD or other mental disorders, animal abuse clinically should be in proper consideration. Animal abuse cannot be investigated as the particular marker that frequently associated with domestic violence, aggressive behavior, or bullying since they are not the only factor to assess. All environmental and personality characteristics of animal cruelty perpetrators have been investigating.

Some of the criminal acts committed by children, teenagers, and adults can probe to a childhood that indicates to the cruelty of animal. Because aggressive behavior in the form of cruelty to children occurs gradually and relate to bio psychosocial. The background of child cruelty continuously growing starts with exploring steps, imitating adult behavior, and unleashing aggressiveness towards animals. Children committing cruelty to animals has a background by its nature curiosity, imitating adult behavior, parenting with neglect, domestic violence, children violence, and peer influence. Parents role are very important, particularly for children when they requires affirmation of their current behavior.

History of $C D$ is an early trigger for antisocial behavior and APD. Research conduct by Gleyzer et al.,( 2002) stated that 48 participants (man) as defendant criminal were diagnosed with Anti-Social Personality Disorder (APD) has a record of committing cruelty to animals in their childhood. Cruelty to animals is taking part of anti-social behavior that associate to conduct disorder in childhood. Some literature calls The Violent Personality to refer to those who are involved in violence in several areas, for example animal cruelty, childhood victimization, witnessing parental violence, lack of empathy, antisocial traits, and permissive parenting (Johnson, 2019). One of the personality disorders associated with aggression is APD.

Cruelty to animals is an indicator that cannot underestimate, since the negative effect on others. Children that identical to innocent behavior harm if infected by aggressive and callous behavior. It can be concluded that callousness becomes one factor that triggers aggressiveness to animals that might occur to humans. The deficit of empathy has numerous contributions to the development of cruel behavior in animals. To sum up all the explanations, one important thing to nurture since childhood is empathy.

One effort to deal with the phenomena is by stimulating empathy since early childhood. Humane Education 
program is one of way to end the cycle of violence by nurture empathy (emotional and cognitive) to humans through teaching goodness to the animal (Juliadilla, 2020). This program teaches animal welfare as the primary concept. Humane Education had applied in several countries such as India, America, and Japan (Juliadilla, Nurhasan, \& Christia, 2020). Unfortunately, this program yet to apply to the curriculum in Indonesia that still prioritizes the academics issues (Juliadilla, Pakaja, \& Iksan, 2020). The closest thing is Character Education. Character education does not talk about animal welfare, but it does represent moral development in children. As one characteristic that requires for adults is empathy, prosocial, and prevent violence. 


\section{REFERENCES}

Acquaviva, E., Ellul, P., \& Benarous, X. (2018).

Developmental

Psychopathology. In Understanding Uniqueness and Diversity in Child and Adolescent Mental Health. https://doi.org/10.1016/B978-0-12815310-9.00001-0

American Psychiatric Association. (2013). Diagnostic and Statistical Manual of. Mental Disorder Edition (DSM-V). Washington: American Psychiatric Publishing.

Ascione, F. R., McDonald, S. E., Tedeschi, P., \& Williams, J. H. (2018). The relations among animal abuse, psychological disorders, and crime: Implications for forensic assessment. Behavioral Sciences and the Law, 36(6), 717-729.

https://doi.org/10.1002/bsl.2370

Born, P. (2018). Regarding Animals: A Perspective on the Importance of Animals in Early Childhood Environmental Education. International Journal of Early Childhood Environmental Education, 5(2), 46-57.

Camelia. (2019). Bawa Ayam yang Ditabraknya ke Rumah Sakit, Aksi Bocah Ini Tuai Pujian.

Chan, H. C. (Oliver), \& Wong, R. W. Y. (2019). Childhood and adolescent animal cruelty and subsequent interpersonal violence in adulthood: A review of the literature. Aggression and Violent Behavior, 48, 83-93. https://doi.org/10.1016/j.avb.2019.08. 007

Dadds, M. R., Whiting, C., Bunn, P., Fraser, J. A., Charlson, J. H., \& PirolaMerlo, A. (2004). Measurement of Cruelty in Children: The Cruelty to
Animals Inventory. Journal of Abnormal Child Psychology, 32(3), 321334.

Gleyzer, R., Felthous, A. R., \& Holzer, C. E. (2002). Animal Cruelty and Psychiatric Disorders. The Journal of the American Academy of Psychiatry and the Law, 30(2), 257-265.

Gullone, E. (2011). Conceptualising animal abuse with an antisocial behaviour framework. Animals, 1(1), 144-160.

https://doi.org/10.3390/ani1010144

Gullone, E. (2012). Animal Cruelty, Antisocial Behaviour, and Aggression. In Animal Cruelty, Antisocial Behaviour, and Aggression. https://doi.org/10.1057/978113728454 9

Gullone, E. (2014). Conceptualising Animal Abuse with an Antisocial Behaviour Framework.

(May). https://doi.org/10.3390/ani1010144

Hare, R. D., \& Neumann, C. S. (2009). Psychopathy: assessment and forensic implications. Canadian Journal of Psychiatry. Revue Canadienne de Psychiatrie, 93-124. https://doi.org/10.1093/med/97801995 51637.003.0007

Hawkins, R. D., Hawkins, E. L., \& Williams, J. M. (2017). Psychological Risk Factors for Childhood Nonhuman Animal Cruelty. Society and Animals, 25(3), 280-312. https://doi.org/10.1163/1568530612341448

Hawkins, R. D., \& Williams, J. M. (2017). Childhood attachment to pets: Associations between pet attachment, attitudes to animals, compassion, and humane behaviour. International 
Journal of Environmental Research and Public Health, 14(5), 1-15. https://doi.org/10.3390/ijerph1405049 0

Hensley, C., \& Tallichet, S. E. (2005). Learning to be cruel?: Exploring the onset and frequency of animal cruelty. International Journal of Offender Therapy and Comparative Criminology, 49(1), 37-47. https://doi.org/10.1177/0306624X0426 6680

Hensley, C., Tallichet, S. E., \& Dutkiewicz, E. L. (2012). Exploring the age of onset and recurrence of childhood animal cruelty: Can animal cruelty be learned from witnessing others commit it? International Journal of Offender Therapy and Comparative Criminology, 56(4), 614-626. https://doi.org/10.1177/0306624X1140 5480

Jegatheesan, B., Enders-Slegers, M. J., Ormerod, E., \& Boyden, P. (2020). Understanding the link between animal cruelty and family violence: the bioecological systems model. International Journal of Environmental Research and Public Health, 17(9). https://doi.org/10.3390/ijerph1709311 6

Johnson, S. A. (2018). Animal cruelty, pet abuse \& violence: the missed dangerous connection. Foresic Research $\mathcal{E}$ Criminology International Journal, 6(5), 403-415. https://doi.org/10.15406/frcij.2018.06. 00236

Johnson, S. A. (2019). Understanding the violent personality: antisocial personality disorder, psychopathy, \& sociopathy explored. Foresic Research $\mathcal{E}$ Criminology International Journal,
$7(2)$,

76-88.

https://doi.org/10.15406/frcij.2019.07. 00267

Juliadilla, R. (2020). Humane Education as a Method of Empathy Character for Children in School. WASKITA: Jurnal Pendidikan Nilai Dan Pembangunan Karakter, 4(2), 13-24. https://doi.org/10.21776/ub.waskita.2 020.004.02.2

Juliadilla, R., Nurhasan, U., \& Christia, D. (2020). Pembelajaran Humane Education di Kurikulum 2013 Menggunakan Media Animasi.

Juliadilla, R., Pakaja, F., \& Iksan, M. (2020). Animal Education Berbasis Animasi Sebagai Media Belajar Interaktif Dengan Pendekatan Tematik (Implementasi Pendidikan Karakter Dalam Kurikulum 2013). Jurnal Pengabdian Masyarakat (JPM17), 05(01), 20-30.

Kavanagh, P. S., Signal, T. D., \& Taylor, N. (2013). The Dark Triad and animal cruelty: Dark personalities, dark attitudes, and dark behaviors. Personality and Individual Differences, 55(6), 666-670. https://doi.org/10.1016/j.paid.2013.05. 019

Levitt, L., Hoffer, T. A., \& Loper, A. B. (2016). Criminal histories of a subsample of animal cruelty offenders. Aggression and Violent Behavior, 30, 48-58. https://doi.org/10.1016/j.avb.2016.05. 002

Longman, T., Hawes, D. J., \& Kohlhoff, J. (2016). Callous-Unemotional Traits as Markers for Conduct Problem Severity in Early Childhood: A Metaanalysis. Child Psychiatry and Human Development, 47(2), 326-334. 
https://doi.org/10.1007/s10578-0150564-9

McDonald, S. E., Cody, A. M., Booth, L. J., Peers, J. R., O'Connor Luce, C., Williams, J. H., \& Ascione, F. R. (2018). Animal Cruelty among Children in Violent Households: Children's Explanations of their Behavior. Journal of Family Violence, 33(7), 469-480. https://doi.org/10.1007/s10896-0189970-7

McEwen, F. S., Moffitt, T. E., \& Arseneault, L. (2014). Is childhood cruelty to animals a marker for physical maltreatment in a prospective cohort study of children? Child Abuse and Neglect, 38(3), 533-543. https://doi.org/10.1016/j.chiabu.2013. 10.016

Nunes, S. A. N., Faraco, A. M. X., Vieira, M. L., \& Rubin, K. H. (2013). Externalizing and internalizing problems: Contributions of attachment and parental practices. Psicologia: Reflexao e Critica, 26(3), 617625. https://doi.org/10.1590/S010279722013000300022

Pradnyawati, D., \& Ardjana, I. G. A. E. (2015). Gangguan Tingkah Laku Pada Anak. Jurnal Ilmiah Kedokteran, 46(2), 119-125.

Protopapadaki, V. (2016). Study on education and information activities on animal welfare. 1-190. Retrieved from www.irta.es

Rodrigo, C., Rajapakse, S., \& Jayananda, G. (2010). The ' antisocial' person: an insight in to biology, classification and current evidence on treatment. (July). https://doi.org/10.1186/1744-859X-931
Samuels, W. E., Meers, L. L., \& Normando, S. (2018). Improving Upper Elementary Students' Humane Attitudes and Prosocial Behaviors through an In-class Humane Education Program. Anthrozoos, 29(4), 597-610.

https://doi.org/10.1080/08927936.2016 .1228751

Santrock, J. . (2011). Life-Span Development Perkembangan Masa Hidup (13th ed.; I. Sallama, Novietha, Ed.). Jakarta: Erlangga.

Walters, G. D. (2017). Animal cruelty and firesetting as behavioral markers of fearlessness and disinhibition: putting two-thirds of Macdonald's triad to work. Journal of Forensic Psychiatry and Psychology, 28(1), 1023.

https://doi.org/10.1080/14789949.2016 .1244856

Wellson, S., \& Gandha, M. V. (2015). Pusat Edukasi Tentang Hewan Peliharaan. Jurnal Kajian Teknologi, 11(1), 28-42. Retrieved from http://journal.untar.ac.id/index.php/t eknologi/article/download/617/505

Wijana, E. P. ., \& Anggreini, S. . (2020). ABG si Pembunuh Bocah 6 Tahun Suka Siksa Hewan, Benarkah Ciri Psikopat?. 